\title{
For a comparative history of Alsace and Transylvania ${ }^{\dagger}$
}

\author{
Valentin Trifescu* \\ Faculty of Letters, "Alexandru Ioan Cuza" University, Bd. Carol I 11, 700506 Iaşi, Romania
}

\section{Article info}

History:

Received May 6, 2014

Accepted June 3, 2014

Published January 13, 2015

Key words:

Alsace

Transylvania

comparative analysis

\begin{abstract}
Alsace and Transylvania are two historical border provinces which have been intensely debated throughout history and which have always been interrelated with each other in discourses of politicians as well as of intellectuals and of historians. By our study we would like to set forth a plea for a comparative history of Alsace and Transylvania (as two border provinces) and to yield a first set of arguments in favour of such a scientific endeavour. Once established the advantages and the methods upon which an inquiry of comparative history rests, we could better understand the particular identity and the ways in which these two sideline provinces have related to their centres of power. Thus the monolithic and exclusive national history may be replaced by a fragmentary and/or peripheral standpoint which would bring to light different aspects concerning local or regional history, regionalism or the relationship between the centre and its periphery.
\end{abstract}

To Jean-Noël Grandhomme

\section{Mitteleuropa from the Vosges to the Carpathians}

Countless arguments could be called forth in favour of a history in which Alsace and Transylvania should be compared to each other. One might equally find counterarguments to it, among which the strongest one could be the contestable question which would significantly diminish the importance of the chosen subject: why should Alsace be compared to Transylvania and not to Sicily or to any region on planet Mars? ${ }^{1}$

The research methodology, on the other hand, has a set of serious problems quite its own for it is very hard to determine precisely, as Veyne (1999, p. 162) puts it, "where history begins at all [and] where comparative history begins"; since every historian is actually, like any researcher, a comparatist.

Nevertheless the reasons for which a comparative history of Alsace and Transylvania should be carried out are even more. A mirror approach to them would allow us to observe how these two border provinces par excellence related to their centres of power throughout history. Then again, we could analyse how centralization and assimilation policies were applied in the two border regions, intensely disputed by France and Germany, on the one hand, and by Romania and Hungary, on the other hand. Last but not least, we could better understand the inner mechanisms that led to the formation of a sideline/border regional identity in the context of the nineteenth and twentieth centuries' nationalism.

\footnotetext{
${ }^{\dagger}$ This work was supported by the strategic grant POSDRU/159/1.5/S/140863, Project ID 140863 (2014), co-financed by the European Social Fund within the Sectorial Operational Program Human Resources Development 2007-2013.

*Email address: valentintrifescu@yahoo.fr.

${ }^{1}$ As far as we know, a collective volume has been published up to now in which Alsace, Lorraine, Trento, and Trieste were analysed as border regions (see Ara \& Kolb, 1995, passim).
} 
We have no intention to exceed the cultural and geographical notion of Mitteleuropa, but we believe that Transylvania and Alsace are two historical regions located on the East-West axis of Central Europe ${ }^{2}$, each placed on its extremities, where several nations and cultures coexisted, and where German has been the lingua franca (especially for the elite) until the middle of the twentieth century (Le Rider, 2001, p. 121).

In favour of such a Mitteleuropa from the Vosges to the Carpathians there could also be invoked less scientific arguments, in the classical sense of the word, but which would not leave any Transylvanian historian who had contact with Alsace indifferent. More precisely, the history of nutrition might be of help. Both in Alsace and in Transylvania white wine ${ }^{3}$ varieties are the most frequently cultivated oneswhich is typical of German and of Central European space-whereas in the other regions of France and of Romania red wine types are most commonly cultivated. In addition, a host of Alsatian traditional culinary specialities remind us of the taste of Transylvanian dishes.

Furthermore, other aspects of the past could also be appealed to, not as solid evidence but as convincing reasoning which would emphasize the common historical destiny of the inhabitants of Alsace and Transylvania, and which would place them within Mitteleuropa as in a closed circle. A part of the colonized medieval Transylvanian Saxons, who brought along a real civilizing infusion into the Carpathian Arc, came from the Rhine and Moselle valleys.

All our concerns with respect to the choice and especially to the justification of a comparative study of Alsace and Transylvania (Trifescu, 2013, passim) vanished the moment we noticed that Hungarian scientist are also interested in such a subject matter and in its methodological approach ${ }^{4}$. For instance, Máté Rigó is currently working on a doctoral thesis whose main aim is to highlight the economic and social problems of the two border regions which have been integrated, until the end of World War I, into the administrative framework of the Central Powers (Germany and Austria-Hungary). Thus we benefit from a wider gnoseological perspective which most fortunately completes our intention to understand the cultural and identity characteristics of Alsace and of Transylvania as border provinces (Trifescu, 2010, p. 73-78; Trifescu, 2014, p. 59-70).

After all these introductory notes, we should mention a reference work published in 1928 by Marc Bloch (1886-1944), where the author displays the benefits which comparative history could bring to scientific research. Regarding the methodology, the prominent historian of the University of Strasbourg, beside giving a number of significant details, claims that the purpose of comparative history is not only to find similarities but also to show the differences between the societies and spaces analysed. Thus,

"Qu'est-ce, tout d'abord, dans notre domaine, que comparer? Incontestablement ceci : faire choix, dans un ou plusieurs milieux sociaux différents, de deux ou plusieurs phénomènes qui paraissent, au premier coup d'œil, présenter entre eux certaines analogies, décrire les courbes de leurs évolutions, constater les ressemblances et les différences et, dans la mesure du possible, expliquer les uns et les autres. Donc deux conditions sont nécessaires pour qu'il y ait, historiquement parlant, une certaine similitude entre les faits observé-cela va de soi-et une certaine dissemblance entre les milieux où ils se sont produits [...]" (Bloch, 2006, p. 350)5 .

\footnotetext{
${ }^{2}$ Our opinion is also sustained by the reflections of Jacques Le Rider, who suggests the same thing, namely that, since the modern age, Mitteleuropa has been made up of the German Empire and of the Habsburg Empire (see Le Rider, 2001, p. 109). In other words, in the first two decades of the twentieth century, geographers like Joseph Partsch and Erwin Hanslik have set Mitteleuropa by the following coordinates: Galați-Sofia-Sarajevo-Trieste and Danzig-Trieste-Odesa (see Droz, 1960, p. 1718). For different geographical, cultural, historical, and political definitions of Mitteleuropa, see Sinnhuber (1953, p. 15-39) and Droz (1960, passim).

${ }^{3}$ About the history of wine in Alsace and its bearings on the cultural and identity peculiarities of the region, see Muller (2010, passim).

${ }^{4}$ Máté Rigó, Money, Reconstruction, Borderlands: social and economic restructuring in Alsace-Lorraine and Transylvania following World War I, (ongoing doctoral thesis), Cornell University, Ithaca, Department of History.

5 "First of all, what does it mean, in our field, to compare? Undoubtedly this: to choose, among one or several different
} 
The purpose of a comparative approach is ultimately to regain and better understand the local and regional history, providing that a third discourse (a regional/regionalist discourse) would be brought to light which could obtain in certain cases the value of viable solutions for dialogue, as opposed to the national/nationalist strong discourses which are caricatural and incompatible by definition. From this perspective, Marc Bloch stated that:

“[...] L'histoire comparée, rendue plus aisée à connaître et à servir, animera de son esprit les études locales, sans lesquelles elle ne peut rien mais qui sans elle n'aboutiraient à rien. En un mot, cessons, si vous le voulez bien, de causer éternellement, d'histoire nationale à histoire nationale, sans nous comprendre. Un dialogue entre des sourds, dont chacun répond tout de travers aux questions de l'autre, c'est un vieil artifice de comédie, bien fait pour soulever les rires d'un public prompt à la joie ; mais ce n'est pas un exercice intellectuel bien recommandable" (Bloch, 2006, p. 380$)^{6}$.

\section{Parallelism between the "Alsatian case" and the "Transylvanian case"}

Our readers are well acquainted with the fact that Romania (initially the Romanian principalities) had a privileged relationship with France in the nineteenth and twentieth centuries, and it is also known that French culture and civilization had a dominant and decisive impact on the formation of the young Carpathian-Danubian-Pontic state.

Romanian intellectuals related to Alsace especially in order to solve the national and regional situation of Transylvania. After the Franco-Prussian War (1870-1871), the "Alsatian case" became a paradigmatic case for entire Europe. More precisely it was Alsace-Lorraine, the new administrative province of the German Empire, which symbolized par excellence a territory dominated by profound convulsions of identity and minority issues, representing at the same time the apple of discord between the two nations on the offensive.

After 1919, Alsatian example was so obviously imitated by the Romanian authorities that Transylvanian Romanian higher education system was established following the "Strasbourg model", also applied by Czechoslovaks at Bratislava (Sălăgean, 2012, p. 128, 132). As a consequence of the proposal made by several Romanian intellectuals, among which Nicolae Drăescu, Nicolae Drăganu, and Onisifor Ghibu, the Ruling Council nationalized the old Hungarian university of Cluj, settling it on Romanian basis. Right from the beginning this new institution was meant to be free from animated regionalist and particularist spirit, "upholding, on the contrary, the need to integrate it as soon as possible into the Romanian university system" (Sălăgean, 2012, p. 128). By implementing these ideas, it actually took place the nationalization of Transylvanian higher education system, in which the new regional elite was moulded in the Romanian spirit promoted by the central government of Bucharest. Several other proposals were also made concerning the reorganization of Transylvanian higher education system which, however, did not win their case.

During the Romanian royal couple's visit in Paris, in April 1924, it was once again pointed out that France and Romania had common interests regarding the integration of the new provinces into the national administrative state, on the one hand, and regarding the solutions to the problem of German and

social environments, two or more phenomena which at first sight seem to have some kind of analogy between them, to describe their curves of development, to determine the similarities and the differences between them and, if possible, to explain them. Thus two conditions are required to exist, historically speaking, a particular similarity between the observed facts-naturallyand a certain difference between the environments in which they occur [...]".

6"[...] Comparative history, which became better known and easier to use, will inspire local studies, without which it can do nothing, but which, without them, would not lead to anything. In short, let's stop, if you wish, gossiping about one national history or another without understanding each other. A dialogue of the deaf, in which everyone answers awry to each other's questions, is an old comedy trick, perfect for making a public eager for joy to laugh, but it is not a highly recommended intellectual exercise". 
Hungarian revisionism ${ }^{7}$, on the other hand. As Jean-Noël Grandhomme fairly stated, "Pour L'Indépendance roumaine cette visite imprévue revête une grosse importance politique. Les traités de 1919-1920, qui ont rendu l'Alsace et la Lorraine à la France, ont apporté l'unité nationale à la Romanie. L'intérêt des deux pays de sopposer à leur révision, réclamée par l'Allemagne et la Hongrie, afin de maintenir la paix en Europe [...]" (Grandhomme, 2000, p. 146) ${ }^{8}$. The two monarchs particularly insisted that, during their visit in Paris, they should stop first at Strasbourg, where they were most welcomed by the local authorities and townspeople and with all the splendour proper to high-ranking dignitaries. As part of the welcome ceremony, Queen Marie (1875-1938), as a writer, was appointed doctor honoris causa of the University of Strasbourg (Grandhomme, 2000, p. 149; Grandhomme, 2011, p. 800). This high academic distinction awarded to the queen of Romania should be interpreted rather as a political act-consistent with the official policy of the State-intended by the French academics of Strasbourg. It is also significant, however, that in 1919, soon after the French nationalized the University of Strasbourg, the historian Nicolae Iorga (1871-1940) - known for his nationalist perspective on Romanians' history, especially of those from Transylvania-was appointed doctor honoris causa (Grandhomme, 2000, p. 145). Thus we can better understand the impact of the French model implemented in Alsace on Transylvanian Romanian authorities.

Not only Romanians were inspired by the Alsatian model (Lorraine has always played a secondary role in all this discussion, just like Banat, which has always been placed on "the trailer" of Transylvania) and by the means by which France has recovered the territory between the Vosges and the Rhine. It was a mutual association. In the discourses of the French and Romanian intellectuals, Alsace(-Lorraine) became the "French Transylvania" and Transylvania became the "Romanian Alsace(-Lorraine)".

In the nineteenth century, very few of the French scholars were concerned with the national fate of Romanians in the Austro-Hungarian Empire. At that time, Romanians' Transylvania did not represent a topic of major interest for French culture and politics, chiefly given the fact that, in the time of King Carol I, Romania was enclosed within the political and military system of the Central Powers. Until World War I, we could mention the name of the historian and professor Ernest Denis (1849-1921), who paid particular attention to Romanians in the Dual Monarchy (Grandhomme, 1997, p. 223). As a matter of fact, as Jean-Noël Grandhomme observed:

"La Guerre allait faire connaître la Transylvanie au public français, en la présentant, de façon très parlant, comme l'Alsace-Lorraine de la Roumanie. À partir de la signature de l'accord du 17 août 1916-qui consacre solennellement l'alliance entre la Roumanie et l'Entente-la France soutint officiellement le droit à la Roumanie d'annexer la Transylvanie” (Grandhomme, 1997, p. 223)9.

Beside the Great War, general Henri-Mathias Berthelot (1861-1931) played an important role in solving the "issue of Alsace" from the perspective offered by the case of Romanian Transylvania. It is certainly

${ }^{7}$ During 1917-1918, after Romania entered the war in order to gain Transylvania, several prisoner camps were established in Alsace-Lorraine where Romanian soldiers were taken to and where they received particularly harsh treatment, mainly because Romania had switched to the side of Entente. On the occasion of the opening of the Romanian military cemetery in Soultzmatt, inaugurated by King Ferdinand and Queen Marie on April 9, 1924, the group of Colmar and the surroundings of the "Union des pères et de mères dont les fils sont tombés" wrote a letter in which it was outlined that France and Romania had ties and common interests in territorial unity: "Ils reposent, morts pour leurs Patrie, en terre amie, vénérés de tous, un soulagement pour leurs familles et leurs peuples. Ils méritent doublement notre reconnaissance, ayant aussi aidé dans cette grande tourmente à la délivrance de notre petite Patrie, l'Alsace-Lorraine! / El les Roumain enterrés dans notre pays ont droit quả leur cercueil la foule vienne et prie!" (see Nouzille, 1997, p. 64, cover 4).

8"For Romania's Independence this unexpected visit bears a great political significance. The treaties of 1919-1920, which gave back Alsace-Lorraine to France, brought Romania its national unity. The interest of both countries to oppose to their revision, requested by Germany and Hungary, to maintain peace in Europe [...]".

9"The war was supposed to make Transylvania known to the French public, presenting it, in a very oral way, as being the Alsace-Lorraine of Romania. After the agreement signed on August 17, 1916-which solemnly consecrated the alliance between Romania and the Entente-France sustained Romania's right to annex Transylvania”. 
not a mere coincidence that, after his mission in Romania was over, general Berthelot was appointed military governor of Metz, in October 1919, and thereafter military governor of Strasbourg, in spring 1923 (Grandhomme, 2011, p. 737,771). Whether the Parisian authorities wanted to specifically emphasize the Alsace-Transylvania analogy or not, by granting Berthelot a leader position over the territories recovered from the Germans, the French government attempted to fructify to the fullest extent the experience accumulated by the career soldier within a historical province intensely disputed and claimed by many, which raised the same severe issues of identity and which implied, at the same time, a laborious administrative integration into the new national structures. In this respect,

"Berthelot découvre une ville et une région [Strasbourg and Alsace n. n.] profondément modifiées à tous points de vues par l'empreinte germanique, et qui s'efforcent de retrouver petit à petit leur caractère français. L'expérience du douloureux passage de la Transylvanie de la loi hongroise à la loi roumaine, dont il a étéle témoin surplace, promet de lui être bien utile [...]" (Grandhomme, 2011, p. 738$)^{10}$.

Both in Romanian cultural and political-diplomatic circles the Alsatian model was constantly invoked during the twentieth century. Even after the events occured in 1989, Romanian authorities-including the president Ion Iliescu - proposed to reach a historic compromise between Romania and Hungary based on the "Franco-German model" (Pomogáts, 2002, p. 200). The real intention of the Romanian party was actually to obtain an irreversible Hungarian agreement to definitively integrate Transylvania into the Romanian state, as it happened in the French Alsace's case.

As the literary historian and critic, Béla Pomogáts, noted especially from a Hungarian perspective, one can not make a credible analogy between Alsace and Transylvania as two border provinces claimed by their neighbour states. According to Pomogáts:

"The history of Hungarian-Romanian controversies can not be compared to the history of Franco-German conflicts, first of all because between the two countries there has never been a rivalry for regional supremacy. Hungary was once part of a large European power, the Habsburg Monarchy, and compared to this authority, Romania was merely an insignificant country which would never have opposed openly to the monarchy (on the contrary, until the First World War, it was its military and political ally), and after 1918, between the two countries there could not have been a rivalry, because none of them was a regional «central power». [...]" (Pomogáts, 2002, p. 201-202).

The motivations upon which the Hungarian literary historian's argumentation rests are mostly historical. One of the major causes of the Franco-German conflict has been the issue of Alsace-Lorraine's ownership, since this territory belonged either to the French, or to the Germans. This, however, was not the case of Transylvania - including here Banat and Partium - which until 1918 has been under Hungarian reign only (except for the Austrian period) (Pomogáts, 2002, p. 200-201). As a much more valid alternative, Béla Pomogáts recommended for Hungarian-Romanian reconciliation in Transylvania the Austro-Italian case of South Tyrol (or Trentino - Alto Adige), where the Germanophile population of the region reached a self-determination benefiting from the external support provided by the Austrian authorities (Pomogáts, 2002, p. 202).

\section{Premier comparisons between Alsace and Transylvania}

Although the World War I consecrated in Romanian culture the "Alsatian issue" for the case of Transylvaniaand as shown above, the "Transylvanian issue" for the case of Alsace-, dating back to 1909, there was

\footnotetext{
10 "Berthelot discovers a city and a region deeply transformed, in all respects, by German influence and which were struggling to regain, little by little, their French character. The painful experience of Transylvania's transition form Hungarian law to Romanian law, which he witnessed, announced to be very helpful to him [...]"
} 
already written a unique and extremely important study concerning our research subject, in which AlsaceLorraine was compared to Transylvania. This study we owe to Onisifor Ghibu (1883-1972), who in the academic year 1907-1908 came for a semester to the Faculty of Letters and Philosophy at the University of Strasbourg obtaining a scholarship offered by the "Transylvania" Society (Sigmirean, 2000, p. 718)"11.

From the very beginning of the study, expanded along 59 pages, the author has proposed to speak to Romanian readers about "one of the most interesting patches of land in Europe", which up until that moment has been less known to Romanians, and which by the first decade of the twentieth century had become, "the new arena of struggle between two peoples extremely cultivated and hostile to each other" (Ghibu, 1909, p. 3).

Due to his pedagogical preoccupations, Onisifor Ghibu paid more attention to aspects of school life in Alsace-Lorraine-especially in areas with a majority francophone population-which ultimately served as analogical model for Transylvanian Romanian education system.

Describing his trip to Alsace-Lorraine, the Romanian intellectual pointed out various important details about the situation of the national and regional identities in Alsace and Lorraine and about their linguistic, political, administrative, religious, and cultural problems.

Onisifor Ghibu described Alsace-Lorraine as a territory which makes foreigners have "the most contradictory impressions". Anyone who comes into contact for the first time with these regions would be disrupted at first by the great number of different, more or less official discourses and opinions, which develop the French and German views on the status of the two historical provinces. "If you undoubtedly believed the German data, you'd think that everything here has been Germanized and that the few French remains do not represent anything at all, and if you let yourself be led by the French data, sometimes overwroughtly optimistic, you'd think that, at least to a very large extent, everything here is French down to its foundation" (Ghibu, 1909, p. 4-5). The author of the study, however, does not let himself be seduced by either of these national theories, choosing instead the "middle path [which] seems to be the true one", in which one might identify both the notable progress of Germanization and the resistance of old French traditions to the different elements coming from the East Rhine (Ghibu, 1909, p. 5).

The strongest impression, upon which Alsace and Lorraine were described as regions of extreme contrasts, was determined by the demographic reality itself. According to the Transylvanian intellectual, the unique peculiarity of these regions was due to the cohabitation of two completely different nations, which, moreover, have been enemies, a situation that reminds us of Transylvania where Onisifor Ghibu came from.

"[...] For all over the place you will find two peoples fundamentally opposite to each other by their nature, by their occupations, by the way they go out into the world and by the aims they want to achieve all in different ways. The tenacious German, who has a strong sense of patriotism breathing everywhere and in the most various forms, sometimes very offensive to others, who is proud of nowadays' great German name and ready to sacrifice everything in order to exalt this name, characterized by an associationist spirit which would show the world everything it has, is completely different from the sentimental French who lives his life more and more for himself, who respects his country rather out of ambition, who loves his language because others love it and because it is beautiful rather than because it is his own, and who would not seek wherever he goes, like Germans do, the power in union, but rather in trust and in truth, and finally the French who even in his home would cross your path as a «magister elegantiarum» of the material life rather than as a persistent fighter for an idea which only with great difficulty could be achievedthese two enemies who will never reconcile, here in Alsace-Lorraine appear in circumstances that would seduce even the most well informed" (Ghibu, 1909, p. 4).

As we have seen, all the qualities and defects of the two nations have been listed above, which ultimately gave birth to stereotypes and prejudices.

\footnotetext{
${ }^{11}$ In the same academic year Onisifor Ghibu studied one semester at the University of Tübingen (Sigmirean, 2000, p. 719).
} 
The reading grid by which Onisifor Ghibu analysed Alsace-Lorraine was that of a Transylvanian Romanian from the Austro-Hungarian Monarchy. It was quite strange for him how Alsatians and the inhabitants of Lorraine accepted German government without much resistance, content with a situation of compromise by which they obtained the recognition of only a few cultural and administrative rights. In the Romanian intellectual's view, the two historical provinces were made up of French and Germans, the existence of regional identities being perceived as unusual and incomprehensible. Nevertheless, Ghibu identified quite fairly the Alsatian (and Lotharingian) regionalist movement which was based on and determined by the old local traditions and customs: "With all their ancient civilization, and perhaps precisely because of this - and with all their commercial and cultural ties with France, the so-called national consciousness is a completely different thing for them, they speak of «Alsatian blood», of «Alsatian nation» and of «Lorraine's nation»-which for us is something almost incomprehensible because the state of affairs encountered here can not be found in any other place [...]" (Ghibu, 1909, p. 8).

Alsatian particularism was expressed and developed within the framework of an autonomist policy which, in the Romanian intellectual's view, was different from that of the Transylvanian Romanians. This type of particularism did not raise a radical issue for the territorial and political separation from Germany. According to Onisifor Ghibu, the denationalization process was much more wide-ranging in Alsace-Lorraine than in Transylvania. Unlike Transylvanian Romanians, Alsatians and the inhabitants of Lorraine, the "[national] apostles do not have at home"; they also "do not have a literature, literates or a national media" in French language, the newspapers they read "are not written in a national spirit as they are in Transylvania; they have a liberal or Catholic policy and the subject matters they treat are viewed only from this standpoint" (Ghibu, 1909, p. 9, 11) ${ }^{12}$.

Onisifor Ghibu found more differences than similarities between Alsace-Lorraine and Transylvania at the beginning of the twentieth century. In the first case we can notice the manifestation of regional awareness, while in the latter situation expressing the national character was of priority importance for Transylvanian Romanians. As a matter of fact, the specific problems of the Alsatians within Germany have been pointed out and analysed from the particular perspective of the Transylvanian Romanians within Hungary. It was hard for the Romanian intellectual to understand how could Alsatians and the inhabitants of Lorraine be more animated by a regional solidarity rather than by a national spirit. The ethnic composition of the two provinces was perceived only from French or German national standpoint, the midway between the two of them represented by regional identity being perceived as a serious and anachronic matter.

"Apart from all this, there is, however, something tragic, deeply tragic about the lives of these Frenchmen who do not call themselves French but «German on French territory» or «Alsatians» and «Lotharingians». They do not have a national policy, in the modern sense of the word, as Poles, Irish, Finns, Danes, and Romanians of Hungary have, who demand recognition of their nationality and equal rights, in all respects, to those of the ruling nations, they make common cause with the Alsatian and Lotharingian Germans with whom they share the same local traditions and, at least in part, the same French-German dialect and together with whom they ask for nothing but the recognition of Alsace-Lorraine as a German federal state (Bundesstaat) in which they could then attend to their business as required by the interests of the entire country" (Ghibu, 1909, p. 8).

Onisifor Ghibu was ultimately forced to admit the existence of a strong regional identity spirit, which animated the inhabitants of Alsace and Lorraine in the early twentieth century. This extremely welldefined regional identity no longer depended, in its inner composition, on national criteria, so dear to Ghibu, it no longer had the same relevance for Transylvania where, according to the intellectual from

\footnotetext{
${ }^{12}$ Statements which are not entirely correspondent to reality itself. In the period between 1899-1914, it did run a bilingual and Francophile magazine entitled Revue alsacienne illustrée / Illustrirte elsässische Rundschau.
} 
Cluj, Romanians and Hungarians had completely different, irreconcilable, and centrifugal interests ${ }^{13}$. In the statement below, Ghibu found a synthetic formula for regionalism in general, according to which a particular region belongs to those who live there, regardless of their ethnicity.

"I have already mentioned, in another place, that the inhabitants of the country do not regard their country as a French land, but only as a land which belongs to those who inhabit it: French and German gathered in a heap under the name of Alsatians and Lotharingians, hence their battle motto: «L'Alsace-Lorraine aus Alsaciens-Lorrains» ("Alsace-Lorraine of the AlsatiansLotharingians"). They no longer struggle for a reunion with France-their mind is focused on ensuring their country's independence, on gaining the constitution, like any other German state of the Empire" (Ghibu, 1909, p. 11-12) ${ }^{14}$.

\section{Conclusions}

After all the facts stated above, one thing is certain: for Romanian cultural and political elites Alsace represented, in the first half of the twentieth century, a permanent reference model in the dispute regarding the national and regional/regionalist issues which Romanians of the Dual Monarchy and the young Romanian State faced during the inter-war period. Transylvania has often been associated with Alsace since the two provinces went through relatively similar stages regarding the integration of the border territories into the centralized national states, a process which often carried symbolic and national bearings. Although the comparison between Alsace and Transylvania was quite explicit on the Romanian side, on the French side things were not as transparent as in the former case. Throughout the study, however, we have seen that France has also been sensitive to the issue of Transylvania, the specific Alsatian(-Lotharingian) case being quite similar to it.

The particular situation of Alsace-in the history of France and Germany-and of Transylvaniain the history of Romania and Hungary-has been best synthesized by two historians from Strasbourg who have studied with the same passion both the province between the Vosges and the Rhine and the intra-Carpathian province. These two are Jean Nouzille (1926-1997) and Jean-Noël Grandhomme. The former historian captured very well, right from the very subtitle of his book dedicated to Transylvania, the particular status and characteristics of this province, mainly determined by its geographic location, being placed between two great nations, which triggered both numerous contacts and conflicts (Nouzille, 1993, passim). The same extremely synthetic formula ("Terre de contacts et de conflits") matches Alsace as well, which has become during history a real hinterland, a buffer area between two countries on national offensive.

Jean-Noël Grandhomme pointed out the identity problems of especially those who inhabit the two border provinces, who were influenced by a strong sense of either essentially national or essentially regional identity affiliation. The series of conferences inaugurated by the historian from Strasbourg, in 2012, yielded yet another interpretive perspective which is extremely important to our subject matter ${ }^{15}$. The formula "les soldats d'entre-deux", besides its synthetising power by which he defined the complex identity situation of all border territories where the problem of both national and regional identities arose during the Great War, comes to define once again the particular status of Alsace and of Transylvania.

\footnotetext{
${ }^{13}$ Opinion which contradicts reality. There existed Transylvanian intellectuals with Transylvanist beliefs who sustained the coexistence of the three ethnic groups of Transylvania and who supported the idea of a common historical past which united Romanians, Hungarians, and Saxons within the Carpathian Arc. Among them the best known is Károly Kós (1883-1977).

${ }^{14}$ Here is the note of this paragraph: "The strongest evidence which shows that no one protests against annexation-claimed on February 5, 1908 at the Strasbourg Parliament meeting deputy Gilliot, who in 1870 valiantly fought against the Germans - is that the entire population of Alsace-Lorraine requests our state to be a Confederate state, like any other state, in other words, to be an integral part of the German Empire. We ask not to be treated as second hand Germans any more!".

${ }^{15}$ Soldats d'entre-deux. Les Nationalismes minoritaires dans les témoignages des combattants. Europe et Canada (1914-1918), series of conferences inaugurated on November 7, 2012, at the University of Strasbourg (see also Grandhomme, 2010, p. 259273).
} 


\section{Bibliography}

Ara, A. \& Kolb E. (a cura di). (1995). Regioni di frontiera nell'epoca dei nazionalismi. Alsazia e Lorena / Trento e Trieste, 18701914, Il Mulino, Bologna.

Bloch, M. (2006). Pour une histoire comparée des sociétés européennes, in A. Becker and É. Bloch (eds.), L'Histoire, la Guerre, la Résistance, Éditions Gallimard, Paris.

Droz, J. (1960). L'Europe centrale. Évolution historique de l'idée de «Mitteleuropa», Éditions Payot, Paris.

Ghibu, O. (1909). O călătorie prin Alsacia-Lorena. Țara și școlile ei, in "Revista Generală a Învățămîntului”, IV, 4-6, Bucharest.

Grandhomme, J.-N. (1997). Le soutien de la France à la cause transylvaine jusqu'à l'Union d'Alba Iulia (aồt 1916-décembre 1918), in "Revue Roumaine d'Histoire", XXXVI, 3-4, Bucharest.

Grandhomme, J.-N. (2000). Les riches heures de la Roumanie à Strasbourg (1923-1926). Le Général Berthelot, Gouverneur militaire, in "Annuaire de la Société Amis du Vieux Strasbourg", XXVII, Strasbourg.

Grandhomme, J.-N. (2010). 1914-1919: Les combattants alsaciens-lorrains entre deux fidélités? Choix individuels et comportements collectiff, in É. Clementz (ed.), Autorité, liberté, contrainte en Alsace. Regards sur l'bistoire d'Alsace (XIe-XXIe siècles), Éditions Place Stanislas, Nancy.

Grandhomme, J.-N. (2011). Henri-Mathias Berthelot (1861-1931). Du culte de l'offensive à la stratégie globale, Éditions ECPA-D, Ivry-sur-Seine.

Muller, C. (2010). Alsace. Une civilisation de la vigne. Du VIII siècle à nos jours, Éditions Place Stanislas, Nancy.

Nouzille, J. (1993). La Transylvanie. Terre de contacts et de conflits, Revue d'Europe Centrale, Strasbourg.

Nouzille, J. (1997). Le calvaire des prisonniers de guerre Roumains en Alsace-Lorraine (1917-1918), $2^{\text {nd }}$ edition, revised and augmented, with a preface by D. Preda, Éditions Semne '94, Bucharest.

Pomogáts B. (2002). Reconstruirea podurilor (maghiarii și românii) - studii și articole, transl. A. Pop, Editura Pontfix - Pont Kiadó, Sfintu-Gheorghe - Budapesta.

Le Rider, J. (2001). Europa centrală sau paradoxul fragilității, vol. coord. by D. Chetrinescu and C. Vălcan, pref. C. Vălcan, postface by I. Ilian, Editura Polirom, Iași.

Sălăgean, M. (2012). (collab. A.-M. Stan, E. Cismaș, Sz. Tóth), Universitatea din Cluj între 1919 și 1944, in Ov. Ghitta (coord.), Istoria Universității «Babeş-Bolyai», Editura Mega, Cluj-Napoca.

Sigmirean, C. (2000). Istoria formării intelectualității românești din Transilvania și Banat în epoca modernă, pref. N. Bocşan, Presa Universitară Clujeană, Cluj-Napoca.

Sinnhuber, K. A. (1953). Central Europe - Mitteleuropa - Europe Centrale. An Analysis of Geographical Term, in "Transactions and Papers", 20, London.

Trifescu, V. (2010). Introducere în campanilismul alsacian și transilvănean. Hans Haug, Kós Károly și Coriolan Petranu, in "Transilvania", serie nouă, XXXIX (CXV), 10, Sibiu.

Trifescu, V. (2013). Regionalismul în istoriografia de artă. Valorizarea patrimoniului artistic din Alsacia și Transilvania in prima jumaatate a secolului al XX-lea, $\mathrm{PhD}$ thesis, m.s., "Babeș-Bolyai" University of Cluj-Napoca and University of Strasbourg.

Trifescu, V. (2014). Aspecte ale identității de frontieră. Regionalism și geografii identitare în Alsacia interbelică, in P. Pușcaș, V. Trifescu, S. Molnar, V. Ilyes (coord.), Geografii identitare - identități culturale, Presa Universitară Clujeană, Cluj-Napoca.

Veyne, P. (1999). Cum se scrie istoria, transl. M. Carpov, Editura Meridiane, Bucharest.

[Translated by Enikő Pál] 